\title{
Simulated phytoplankton bloom input in top-down manipulated microcosms: comparative effect of zooflagellates, ciliates and copepods
}

\author{
Urania Christaki $^{1,2, *}$, France Van Wambeke ${ }^{1}$ \\ ${ }^{1}$ Microbiologie Marine, C.N.R.S., U.P.R. 223, Campus de Luminy, Case 907, F-13288 Marseille Cedex 9, France \\ ${ }^{2}$ Centre d'Océanologie de Marseille, Station Marine d'Endoume, rue de la Batterie des Lions, F-13 007 Marseille, France
}

\begin{abstract}
Succession of microbial populations and carbon flow were studied experimentally in a 2 -stage linked system where phytoplankton growth was separated from decay or consumption. Three phytoplankton loss processes were considered: bacterial lysis, protozoan grazing and mesozooplankton grazing. An axenic culture of the diatom Phaeodactylum tricornutum was transferred to 3 second-stage microcosms (150 i) kept in the dark. The first vessel (L: lysis batch) contained no herbivores and was top-limited by bacterivorous flagellates, the second ( $\mathrm{G}$ : grazing batch) by ciliates and the third ( $\mathrm{Z}$ : zooplankton batch) by copepods. In the $\mathrm{L}$ container there was no evidence of grazing on phytoplankton; the particle-associated protozoa were abundant $\left(3.7 \times 10^{3}\right.$ cell $\mathrm{l}^{-1}$ ). In the $\mathrm{G}$ vessel, ciliates (up to $96 \times$ $10^{3}$ cell $\mathrm{l}^{-1}$ ) controlled both the phytoplankton and nanoflagellate populations and ciliates ingested phytoplankton at rates from 1.7 to 16 phytoplankton cell ciliate ${ }^{-1} \mathrm{~h}^{-1}$ (average, 7.5 cell ciliate $\mathrm{e}^{-1} \mathrm{~h}^{-1}$ ). The average growth yields for bacterivorous flagellates and ciliates were $35 \%$ and $45 \%$, respectively. In the $Z$ treatment, the concentration of $>10 \mu \mathrm{m}$ protozoa (able to ingest $P$. tricornutum) was apparently kept low due to copepod grazing pressure. Consequently, a considerable fraction of the phytoplankton was channelled through the detrital pathway instead of the classical herbivorous pathway. The general trend of the parameters describing microbial activity was $Z>G>L$. An influence of the complexity of the system on the turnover rate of organic matter was evident with the ratio 'cumulative biomass/POC' in the different vessels showing a lower level of detritus when predators of phytoplankton were present.
\end{abstract}

KEY WORDS: Phytoplankton loss · Microbial food web · Top-down control - Carbon flow

\section{INTRODUCTION}

Blooms have been thought to be induced by natural perturbations in the close balance between production and consumption of the marine plankton. The study of their occurrence and decay may clarify the nature of stabilizing mechanisms (Landry 1981).

Two major fates of phytoplankton biomass, bacterial lysis and protozoan grazing, were recently studied in an experimental system (Van Wambeke 1994). However, in natural environments, the influence of higher consumers (mesozooplankton) on phytoplankton-bacterioplankton coupling may be important (Vaqué et al. 1989). Indeed, mesozooplankton can stimulate bacter-

\footnotetext{
•E-mail: micromar@niou.univ-mrs.fr
}

ial activity by excretion, 'sloppy feeding' and grazing on bacterivorous organisms (Roman et al. 1988, Vaqué et al. 1989).

The eventual fate of phytoplankton may be different depending upon the top predator. In natural environments, the prevailing mechanism for phytoplankton loss depends both on hydrological parameters and plankton community structure (Keller \& Riebesell 1989, Legendre \& Le Fèvre 1989). Furthermore, depending on loss pathways and the number of trophic steps involved, both the quantity and the nature of phytoplankton derived material are expected to be different (Pomeroy \& Wiebe 1988). These variations can in turn influence the bacterial productivity (Eppley et al. 1981, Lucas 1986, Painting et al. 1989, Van Wambeke 1994). 


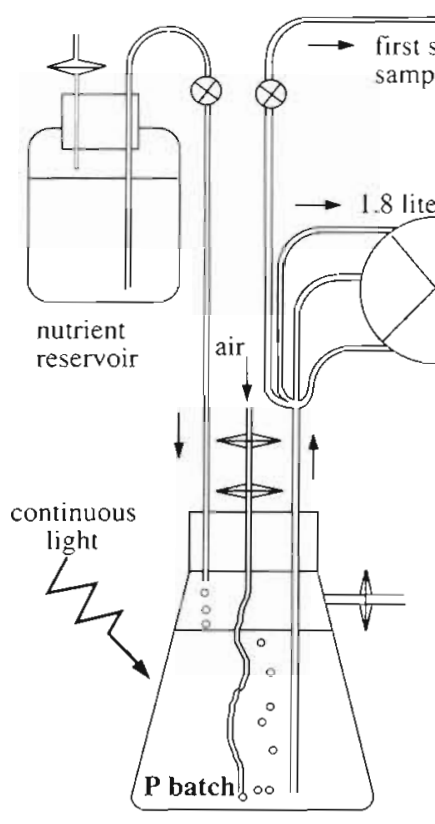

First stage vessel (volume: 6 I) axenic $P$. tricornutum culture
Fig. 1. Schematic diagram of the 2-stage experimental system
In order to examine how the structure of the planktonic community influences the mode of phytoplankton loss, we carried out, in February 1993, a microcosm experiment using a 2 -stage linked system where phytoplankton growth was separated from its decay. Carbon flows and population succession in systems of varying complexity are discussed.

\section{MATERIALS AND METHODS}

Experimental design. A 2-stage system was used in this study (Fig. 1). In the first stage $(\mathrm{P})$ the Phaeodactylum tricornutum was grown axenically in a Tris-free Antia and Cheng 1/10 diluted medium (nitrate $30 \mu \mathrm{M}$, nutrient N/P/Si ratio $=10 / 1 / 6 \mathrm{f}$ in a $6 \mathrm{i}$ culture vessel under continuous light at $20^{\circ} \mathrm{C}$. This culture was maintained in exponential growth phase at a dilution rate of $1 \mathrm{~d}^{-1}$. The outflow was separated into 4 fractions through calibrated peristaltic pumps. One was used to collect first stage samples and the others were dispensed into three $150 \mathrm{l}$ vessels containing 5 and $10 \mu \mathrm{m}$ screened Mediterranean seawater (February 1993, Gulf of Marseilles, about 2 miles offshore at $10 \mathrm{~m}$ depth). Water was screened using a special siphon-filter apparatus using inverse gravity filtration (Baileys Plastic Fabrication Ltd, Canada) on $147 \mathrm{~mm}$ diameter membrane filters (Nuclepore). Our experimental protocol was designed to favor one kind of phytoplankton 'fate' in each vessel (Fig. 2): bacterial

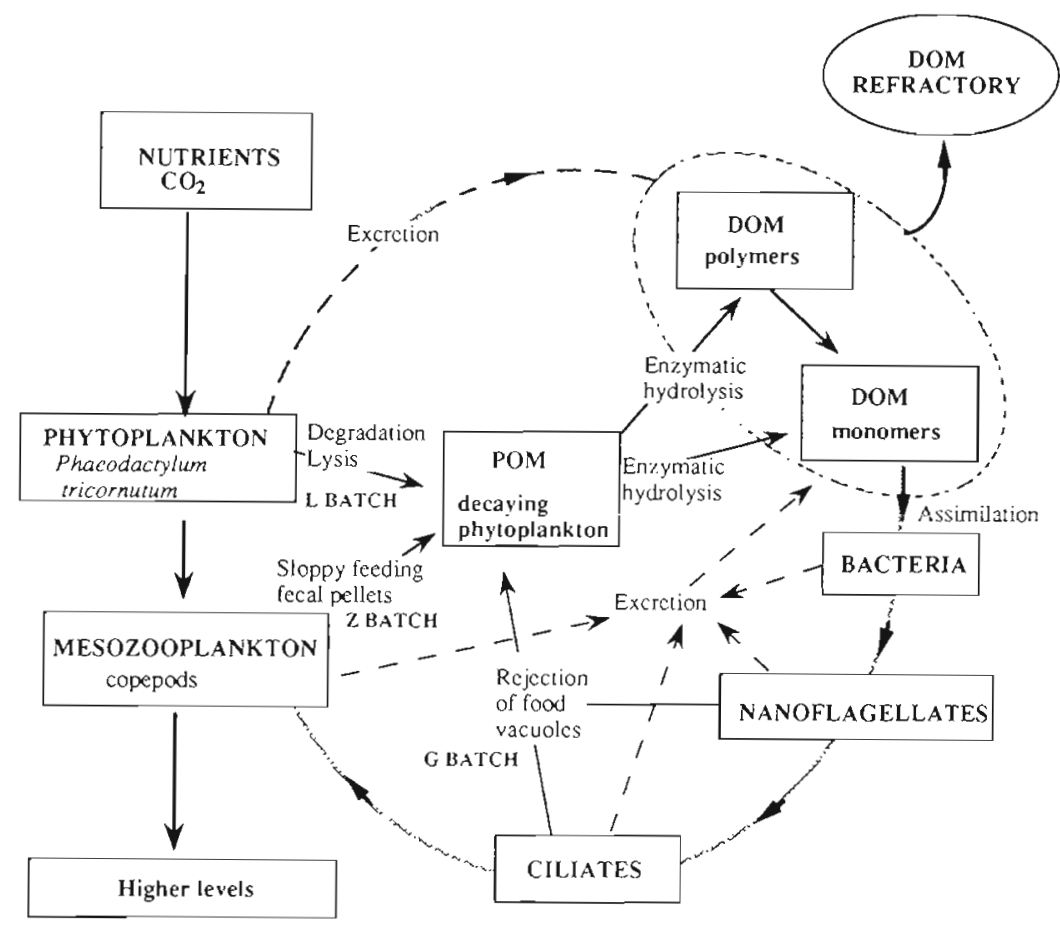

Fig. 2. Microbial food web and its relations with phytoplankton and mesozooplankton. POM: particulate organic material; DOM: dissolved organic material 
lysis ( $\mathrm{L}$ batch), zooplankton grazing ( $\mathrm{Z}$ batch) or protozoan grazing ( $G$ batch). In $L$ the seawater was screened through $5 \mu \mathrm{m}$ to remove protozoa able to ingest $P$. tricornutum. G was devoted to grazing of phytoplankton by protozoa; seawater was screened through a $10 \mu \mathrm{m}$ filter. In $\mathrm{Z}$ the seawater was also screened through $10 \mu \mathrm{m}$ and a population of adult copepods was added (see below). The 3 batches ( $L, G$, Z) were kept at $20 \pm 1^{\circ} \mathrm{C}$, in the dark to prevent any phototrophic production. Between Days 5 and 6, the axenic culture flow was connected to the 3 batches, and a population of adult copepods was added to the $Z$ batch. The axenic culture was added continuously drop by drop into the 3 batches $\left(1.8 \mathrm{l} \mathrm{d}^{-1}\right.$ batch $^{-1}$; Fig. 1) from Day 6 to the end of the experiment.

The $Z$ batch was conceived to study the influence of successive presence-absence-presence of copepods on the structure of $<10 \mu \mathrm{m}$ plankton assemblages. To do this, copepods were added on Day 6, removed on Day 12, and re-introduced on Day 18. Zooplankton removal was performed using gentle screening through a $60 \mu \mathrm{m}$ mesh-size net. The microcosms were mixed with bubbled air (filter-sterilized) and sampled daily for $29 \mathrm{~d}$

Abundance, biomass, particulate organic carbon (POC), and dissolved organic carbon (DOC). Seawater samples were preserved with buffered formalin (final concentration $2 \%$ ), stained with DAPI (final concentration $\left.500 \mathrm{\mu g} \mathrm{l}^{-1}\right)$, filtered and kept frozen $\left(-20^{\circ} \mathrm{C}\right)$. Bacterial samples were collected on $0.2 \mu \mathrm{m}$ black Nuclepore filters and counted by an image analysis system coupled with epifluorescence microscopy. Up to 40 fields were counted per filter, containing 30 to 70 bacteria per field. The coefficient of variation across fields varied from 8 to $17 \%$. Algae and protozoa were retained on $0.8 \mathrm{~mm}$ filters and counted by epifluorescence microscopy. About 100 to 150 protozoa were counted per filter on random $10 \mathrm{~mm}$ strips $(160 \mu \mathrm{m}$ width). The coefficient of variation across strips ranged from 10 to $15 \%$. Protozoa were characterized into 11 different categories and measured with an ocular micrometer, according to their size and morphology. Protozoa able to ingest phytoplankton were distinguished under blue light excitation by the red autofluorescence of their food vacuoles. In the present work, 2 major groups of protozoa are used for simplicity: Group I, mainly free and attached bacterivorous flagellates (Groups Ia and Ib, respectively) measuring 2 to $8 \mu \mathrm{m}_{\text {; }}$ and Group II, protozoa $>8 \mu \mathrm{m}$ able to ingest Phaeodactylum tricornutum (IIa, P. tricornutum grazers except ciliates; and IIb, ciliates). Conversion factors used for calculation of biomass were: $20 \mathrm{fg} \mathrm{C}^{-1 l^{-1}}$ for

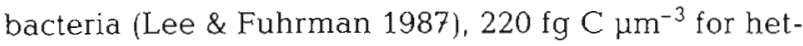
erotrophic flagellates (Børsheim \& Bratbak 1987) and $190 \mathrm{fg} \mathrm{C} \mu \mathrm{m}^{-3}$ for ciliates (Putt \& Stoecker 1989). For $P$. tricornutum the carbon content, calculated from cell counts and particulate organic carbon measurements in the axenic culture, was $9.54 \mathrm{pg} \mathrm{C}$ cell $^{-1}$. Mesozooplankton biomass was estimated from dry weight values, which were then converted into carbon units assuming a $40 \%$ carbon content (Gorsky et al. 1988).

POC was analyzed with a Perkin-Elmer Elemental Analyzer on $100 \mathrm{ml}$ samples retained on precombusted Whatman GF/F glass-fiber filters. For calculation of cumulative biomass we summed the respective biomasses of bacteria, phytoplankton and protozoa. The ratio of cumulative biomass/POC was calculated in order to estimate the importance of detrital material in each vessel. This ratio was used for relative comparisons between the 3 treatments, because a significant fraction of the bacterial biomass can pass through GF/F filters (Cho \& Azam 1988).

DOC concentrations were determined in the axenic culture and in the L, G and $\mathrm{Z}$ batches by the high catalytic oxidation method (Sugimura \& Suzuki 1988).

Bacterial production. Bacterial production was estimated daily by the thymidine method (Fuhrman \& Azam 1982). Duplicate samples $(20 \mathrm{ml})$ and a control were incubated with $20 \mathrm{nM}$ [methyl- ${ }^{3} \mathrm{H}$ ]-thymidine (specific activity $83 \mathrm{Ci} \mathrm{mmol}^{-1}$ ) for $60 \mathrm{~min}$, in the dark and fixed with formalin ( $0.4 \%$ final concentration). The 2 duplicates and the control were filtered through Nuclepore filters $(0.2 \mu \mathrm{m})$; filters were washed with ice-cold 5\% trichloroacetic acid. The percentage of variation between duplicates averaged 14\% (range $<1$ to $37 \%$ ). Linear incorporation and isotope saturation were checked by time and concentration kinetics 3 times in each microcosm. Empirical conversion factors were obtained from diluted (ratio 1/10) batch cultures (Kirchman et al. 1982) performed on Days 8, 19 and 23 for each microcosm. Calculation was carried out by the integrative method according to Riemann et al. (1987). Values obtained varied in the range 0.5 to $1.5 \times 10^{18}$ bacteria (mol $\mathrm{Tdr})^{-1}$. As methodological errors can reach up to $50 \%$ for this parameter, a mean factor of $1 \times 10^{18}$ bacteria $(\mathrm{mol} \mathrm{Tdr})^{-1}$ incorporated was used everywhere for conversion of ${ }^{3} \mathrm{H}-\mathrm{Tdr}$ incorporation into bacterial production.

Mesozooplankton. In order to obtain a direct evaluation of the nutritional strategy of mesozooplankton, additional short-time scale experiments were conducted to measure oxygen consumption in water from the $\mathrm{Z}$ batch. These experiments were performed with freshly collected copepods, on Days 18 and 26 (on Day 18 , a fraction of the same population was added to $Z$ ). The copepods recovered from $Z$ on Days 12 and 29 were inappropriate for such an experiment, because they underwent a stress since the screening of the water of $\mathrm{Z}$ lasted about $2 \mathrm{~h}$. The mesozooplankton were incubated in $300 \mathrm{ml}$ flasks (157 \pm 20 ind.) in sea- 
water from Z, either unfiltered or $0.2 \mu \mathrm{m}$ filtered; flasks without animals served as controls. Triplicate samples were prepared for each trophic condition. The flasks were incubated in the dark for $24 \mathrm{~h}$. The dissolved oxygen was measured with a polarographic electrode (YSI 57 probe, $0.05 \mathrm{ppm}$ precision). The carbon demand for copepods, based on the respiration rates of animals in unfiltered water, was calculated according to Omori \& Ikeda (1984), as follows:

$$
\mathrm{CR}=R / 22.4 \times \mathrm{RQ} \times 12 \quad\left(\mu \mathrm{g} \mathrm{C} \mathrm{mg} \mathrm{dw} w^{-1} \mathrm{~d}^{-1}\right)
$$

where $R\left(\mu l \mathrm{O}_{2} \mathrm{mg} \mathrm{dw}^{-1} \mathrm{~d}^{-1}\right)$ is respiration rate and $\mathrm{RQ}$ $(=0.97)$ is respiratory quotient.

Data analysis. In order to delimit time intervals of succession in the 3 batches, multivariate analysis (nonmetric multidimensional scaling, MDS) was employed. The parameters taken into account for the analysis were: abundance of phytoplankton, bacteria and different size classes of protozoa. The raw data, expressed as number of individuals $\mathrm{ml}^{-1}$, were standardized before comparing the samples according to Field et al. (1982). The Bray-Curtis similarity matrix, formed on group-average sorting, was used for all computations.
The net daily variations $K$ of each parameter $X$, corrected for inflow (axenic culture) and outflow (sampling), were calculated according to Van Wambeke (1994), as follows:

$$
\begin{aligned}
K X(i, j)= & \left(X S_{j}-X S_{i}\right) /(j-i) \\
& +\left(\text { outflow } / V_{i j}\right) \times\left(X S_{j}+X S_{i}\right) / 2 \\
& -\left(\text { inflow } / V_{i j}\right) \times\left(X F_{j}+X F_{i}\right) / 2
\end{aligned}
$$

where $X S_{1}$ and $X S_{1}$ are the concentrations of the considered compound in the second stage $\left(Z, G\right.$ or $L$, units $\left.~^{-1}\right)$, $X F_{j}$ and $X F_{j}$ in the first stage (axenic culture, units $1^{-1}$ ) on Days $j$ and $i$, and $V_{i j}$ is the second stage batch volume (1) between Days $i$ and $j . K X(i, j)$ corresponds to the sum of biological and physical fluxes inside the culture, i.e. the sum of production source minus the sum of losses, and consequently represents a net daily variation.

Bacterial exportation fluxes $\left(\right.$ Exp. $\left.F, \mu g \mathrm{Cl}^{-1} \mathrm{~h}^{-1}\right)$ were calculated from the difference between bacterial production and daily net variation of bacterial biomass. Carbon growth yield of a predator was estimated by the grazing losses of the prey (e.g. bacteria, phytoplankton) compared to changes in predator carbon biomasses (e.g. nanoflagellates, ciliates) during periods in which the predator biomass increased.
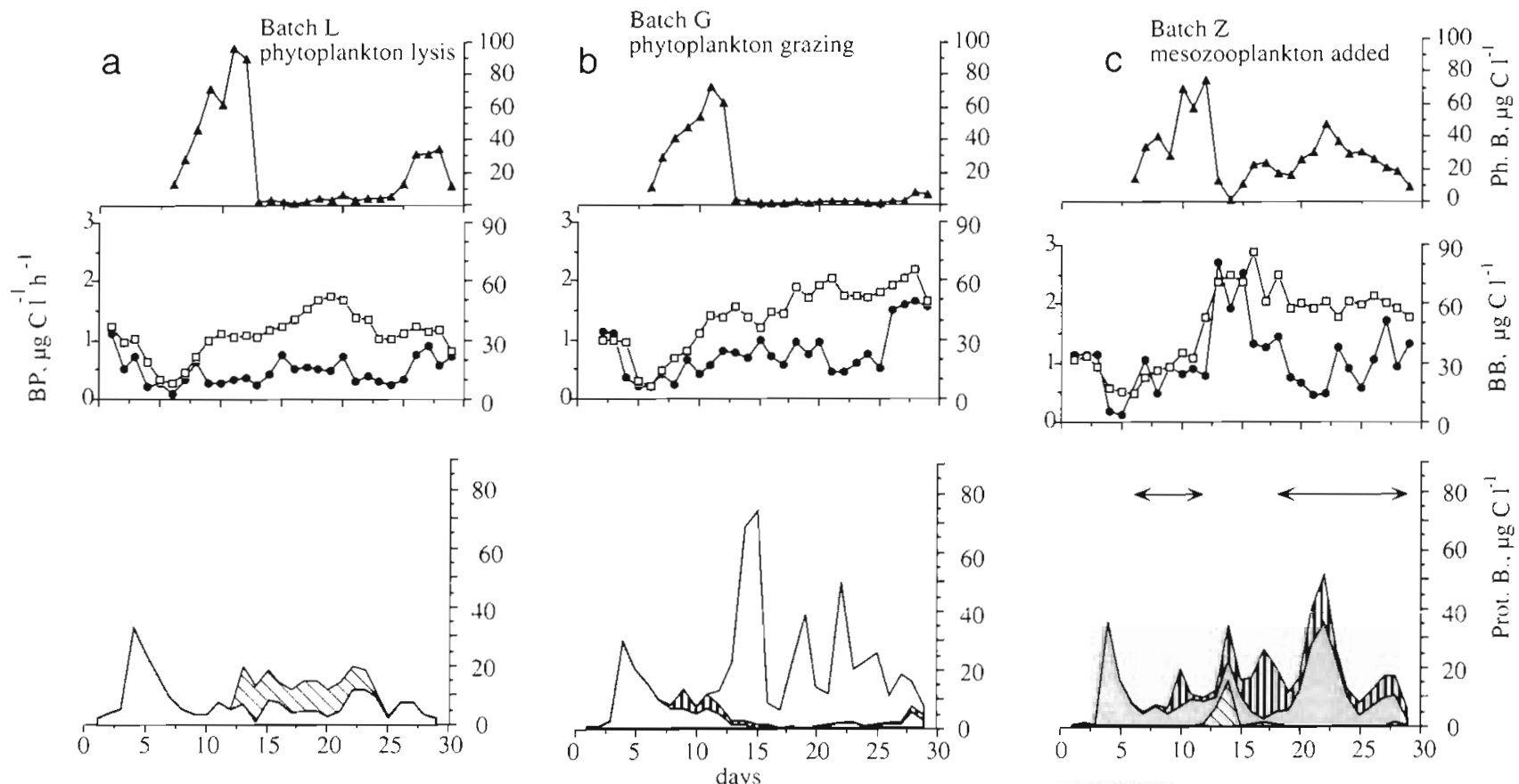

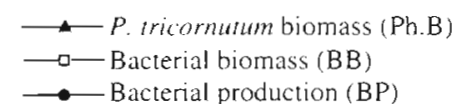

Fig. 3. Biomasses of the diatom Phaeodactylum tricornutum, bacteria, different size classes of protozoa $\left(\mu \mathrm{g} \mathrm{Cl}^{-1}\right)$ and bacterial production ( $\mu \mathrm{g} \mathrm{C}^{-1} \mathrm{~h}^{-1}$ ). (a) $\mathrm{L}$ batch (b) $\mathrm{G}$ batch, (c) $\mathrm{Z}$ batch. Arrows indicate the periods of mesozooplankton presence in the $\mathrm{Z}$ batch
Protozoan biomass (Prot. B.):

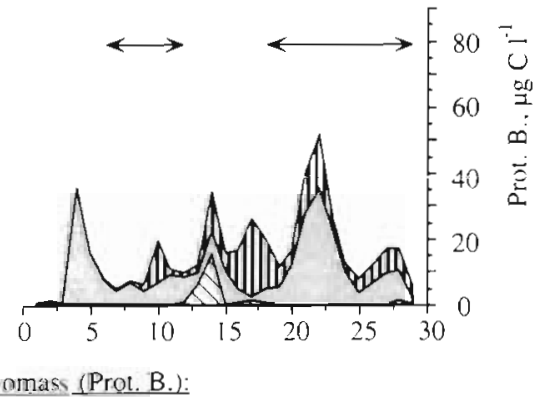

$\square$ Group la = bacterivorous flagellates $2-8 \mu \mathrm{m}$

$\square$ Group $[b=$ bacterivorous flagellates $2-3.5 \mu \mathrm{m}$ associated with particles

II Group $[$ Ia $=\underset{(P . \text { tricornutum }}{\text { prazers })}$

$\square$ Group IIb = ciliates $17 \cdot 22 \mu \mathrm{m}$ ( $P$. rricomurum grazers) 

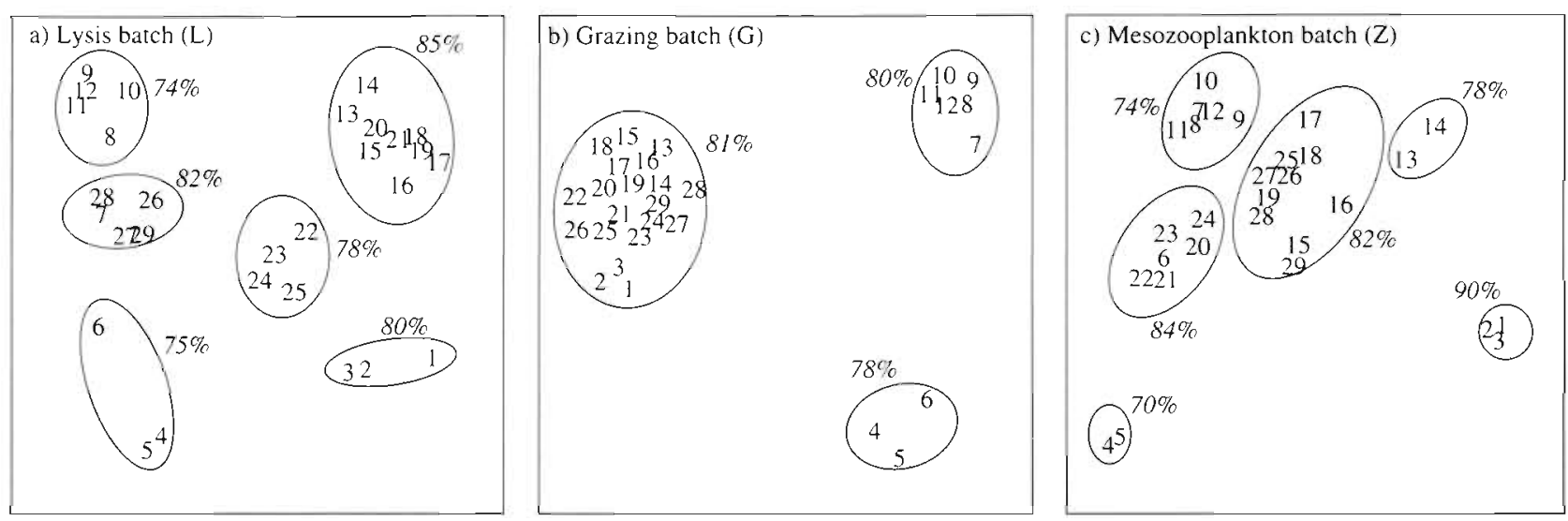

Fig. 4. Non-metric multidimensional scaling (MDS) plots on 2 dimensions, based on Bray-Curtis similarities for organism abundance data after standardization. Numbers on the plots represent the days of the experiment. MDS places the points (here, days) with interpoint distances preserving the rank order dissimilarities exactly so each 'group' has more 'similar samples' than those in separate groups, however every relative distance between samples reflects relative dissimilarity. The average similarity (\%) defining each group of days is also shown. (a) MDS for the L batch, (b) MDS for the G batch, (c) MDS for the Z batch. Stress values were $0.087,0.010,0.069$ respectively

The ingestion rates of protozoa feeding on different kinds of prey (bacteria or phytoplankton) were calculated as the ratio between daily net disappearance of the prey and the corresponding mean abundance of protozoa.

\section{RESULTS}

\section{Succession of microbial communities}

The general pattern of succession showed a remarkable similarity in the 3 containers until Day 12 (Figs. 3 \& 4). An assemblage of bacterivorous flagellates (Group Ia) attained a peak abundance by Days 4 to $5(5.6,6.1$ and $7.5 \times 10^{6}$ cell $\mathrm{l}^{-1}$, in the $\mathrm{L}, \mathrm{G}$ and $\mathrm{Z}$ batches respectively). On Day 5 , the axenic culture was connected to the batches and a population of adult copepods was added to $\mathrm{Z}$. The accumulation of Phaeodactylum tricornutum in the 3 microcosms (Days 6 to 12, Fig. $4 a, b, c)$ was accompanied by a progressive increase of bacterial biomass (Fig. 3). The cumulative biomass/POC ratio (Fig. 5) was similar in the 3 batches during this first phase of the experiment (until Day 12). By Day 13, the phytoplankton population collapsed simultaneously in the 3 batches. At this stage the microbial community became more complex with the appearance, according to batch, of flagellates associated with aggregates (Group Ib, Fig. 3), large flagellates (choanoflagellates, amoebic forms, monads, Group IIa) and ciliates (Group IIb). Hence, at Day 13 the 3 batches started to differentiate from each other (Fig, $4 \mathrm{a}, \mathrm{b}, \mathrm{c}$ ).

In the $\mathrm{L}$ batch, after Day 12, flagellates associated with phytoaggregates were observed. The aggrega- tion phase lasted $9 \mathrm{~d}$ (Days 13 to 21, Fig. 3). These flagellates were of $3.2 \mu \mathrm{m}$ average diameter; some large free ellipsoid flagellates $(4.8 \times 8 \mu \mathrm{m})$ were also present in low abundance (max. $0.03 \times 10^{6} \mathrm{cell}^{-1}$ ). The microscopic analysis revealed that they were not grazing upon Phaeodactylum tricornutum. Between Days 22 and 25 a desegregation phase took place, and a preypredator succession was established between bacteria and flagellates (Fig. 3a). The decrease of bacteria was followed by an accumulation of diatom cells in $\mathrm{L}$ (Days 25 to 28, Figs. 3a \& 4a).

In the $G$ batch the collapse of the phytoplankton population was followed by a considerable increase of ciliates $\left(96 \times 10^{3}\right.$ cell $\mathrm{l}^{-1}$, biomass $83.7 \mu \mathrm{g} \mathrm{l}^{-1}$, Day 15 ; Fig. 3b). Most of the ciliates were of 17 to $22 \mu \mathrm{m}$ diameter (average $20 \mu \mathrm{m}$, Lohmaniella oviformis like). On Days 12 to 14, ciliates consumed the accumulated

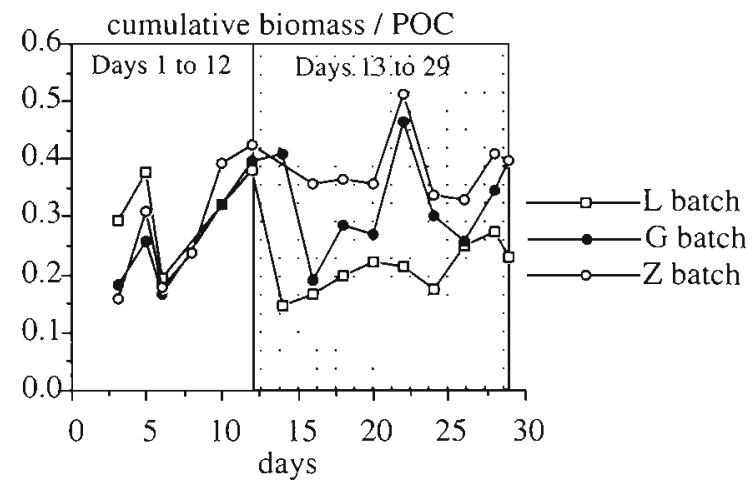

Fig. 5. Ratio of cumulative biomass/POC. Cumulative biomass $\left(\mu g \mathrm{C}^{-1}\right)=$ bacteria + protozoa + phytoplankton biomasses 
phytoplankton. On Day 16 the number of ciliates

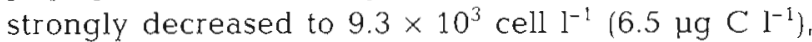
then showed fluctuations until the end of the experiment (Fig. 3b). Flagellates associated with particles were not observed, and the biomasses of other protozoa (Group Ila) were low (Fig. 3b). The minimum value of bacterivorous flagellates $\left\{0.04 \times 10^{6}\right.$ cells $^{-1}$, biomass $0.83 \mu \mathrm{g} \mathrm{C} 1^{-1}$. Day 15) coincided with the maximum biomass of ciliates. The bacterivorous flagellate population (Group Ia) remained low until the end of the experiment, while the bacterial population after Day 15 showed some increase (Fig. 3b). Hence, the multivariate analysis (MDS) revealed a single group of days (Days 13 to 29; Fig. 4b)

In the $\mathrm{Z}$ batch, the collapse of the diatom population was followed by a short period during which we noticed presence of flagellates associated with phytoaggregates (Days 13 to 14 ; Figs. 3c \& 4c); then, the phytoplankton and free living protozoa increased again when copepods were removed (Days 15 to 19). This increase of protozoan biomass was accompanied by both a decrease of bacteria and a parallel accumulation of phytoplankton (Fig. 3c). The pattern of succession of organisms, defined from the MDS (groups of days; Fig. 4c), was not related to the periods of presence of copepods (Days 6 to 12, and 18 to 29; Fig. 4c). The most contrasting feature of the microbial community between the $G$ and $Z$ batches (initially filtered through $10 \mu \mathrm{m}$ ) was the absence of ciliates in the $Z$ batch. Small bacterivorous flagellates $(3.2 \mu \mathrm{m})$, similar to those of $\mathrm{L}$ and $\mathrm{G}$, were numerically dominant in $Z$ (up to $11.8 \times 10^{6} \mathrm{cell}^{-1}$, Day 22), while few large spherical flagellates of $10 \mu \mathrm{m}$ average diameter were present (up to $0.52 \times 10^{6}$ cell $^{-1}$, Day 17 ).

\section{Bacterial abundance and production}

On average, there were more bacteria in the $\mathrm{Z}$ batch $\left(2.5 \pm 1 \times 10^{9} \mathrm{1}^{-1}, \mathrm{n}=29\right)$ than in the batches without copepods $\left(1.6 \pm 0.6\right.$ and $2.0 \pm 0.8 \times 10^{9} \mathrm{l}^{-1}$ in $\mathrm{L}$ and $\mathrm{G}$ respectively). Bacterial production (Fig. $3 \mathrm{a}, \mathrm{b}, \mathrm{c}$ ) was highest in $Z(0.47 \pm 0.2,0.77 \pm 0.4$ and $1.06 \pm 0.6 \mu \mathrm{g} \mathrm{C}$ $\mathrm{l}^{-1} \mathrm{~h}^{-1}$ in $\mathrm{L}, \mathrm{G}$ and $\mathrm{Z}$ respectively). Mean bacterial growth rates were $0.015,0.019$ and $0.022 \mathrm{~h}^{-1}$ in $\mathrm{L}, \mathrm{G}$ and $Z$ respectively.

\section{Zooplankton}

The species added in the $Z$ batch (Acartia clausi, Paracalanus parvus, and Euterpina acutifrons) are among the dominant copepods in the Gulf of Marseilles (Gaudy 1972). The major changes in zooplankton populations consisted in the reduction of the num-
Table 1. Initial and final biomass ( $\mu$ g dry weight $]^{-1}$ ), total abundance (in Z container, $150 \mathrm{l}$ ) and relative taxonomic composition (percentage) of the zooplankton for the 2 periods where zooplankton was added

\begin{tabular}{|c|c|c|c|c|}
\hline & \multicolumn{2}{|c|}{ First period } & \multicolumn{2}{|c|}{ Second period } \\
\hline & Initial & Final & Initial & Final \\
\hline & Day 6 & Day 12 & Day 18 & Day 29 \\
\hline Biomass & 60 & 48 & 22 & 17.8 \\
\hline Total adult individuals & 2053 & 1042 & 625 & 409 \\
\hline Total nauplii + copepodites & 50 & 803 & 0 & 132 \\
\hline$\%$ adult mortality & & 44 & & 32 \\
\hline \multicolumn{5}{|l|}{ Relative composition $(\%)$} \\
\hline Acartia clausi & 86 & 90 & 50 & 50 \\
\hline Euterpina acutifrons & 2 & 3.3 & 33 & 10 \\
\hline Paracalanus parvus & 0.5 & 1.3 & 10 & 30 \\
\hline Others & 12 & 5.4 & 7 & 10 \\
\hline
\end{tabular}

Table 2. Cumulative carbon fluxes between Days 5 and $29(\mu \mathrm{g}$ $\mathrm{Cl}^{-1}$ for $576 \mathrm{~h}$ ). K Pt: net variation of $P$. tricornutum; $K \mathrm{BP}$ : bacterial production; $K B B$ : net variation of bacterial biomass; Exp.F: bacterial exportation flux. Positive values indicate production, negative values indicate consumption

\begin{tabular}{lcccc|}
\hline Batch & $K \mathrm{Pt}$ & $K \mathrm{BP}$ & KBB & Exp.F \\
\hline L & -657 & 256 & 26 & -230 \\
$\mathrm{G}$ & -642 & 433 & 56 & -377 \\
$\mathrm{Z}$ & -566 & 612 & 56 & -556 \\
\hline
\end{tabular}

ber of adults (Table 1). The mortality of adults was $44 \%$ for the first (Days 6 to 12 ) and $32 \%$ for the second period (Days 18 to 29), values similar to those reported in the literature in analogous experiments (Vaqué et al. 1989). Respiration rates were $55 \%$ and $25 \%$ higher in flasks containing unfiltered water than those containing $0.2 \mu \mathrm{m}$ filtered water on Days 18 and 26 respectively.

\section{Carbon fluxes}

The total phytoplankton consumed (Eq. 2) through the microbial food web during the Day 5 to 29 period were almost equal in the $L$ and $G$ batches and somewhat lower in the $Z$ batch $(Z<G<L$, Table 2$)$. The dissolved organic carbon (DOC) fueled by the axenic culture constituted an alternative carbon source for bacteria. DOC data available concerned Days 5 to 18 . On average, bulk phase concentration of the DOC was $2112 \mu \mathrm{g} \mathrm{C}^{-1}$ in the axenic culture, and 1180, 1261, $1263 \mu \mathrm{g} \mathrm{Cl}^{-1}$ in L, G and Z respectively. An estimate of the bacterial growth yield was calculated as follows

$$
\text { Growth yield }=K \mathrm{~PB} /(K \mathrm{DOC}+K \mathrm{Pt})
$$

where $K P B, K D O C$ and $K$ Pt were: bacterial production, net variation of dissolved organic carbon and net 


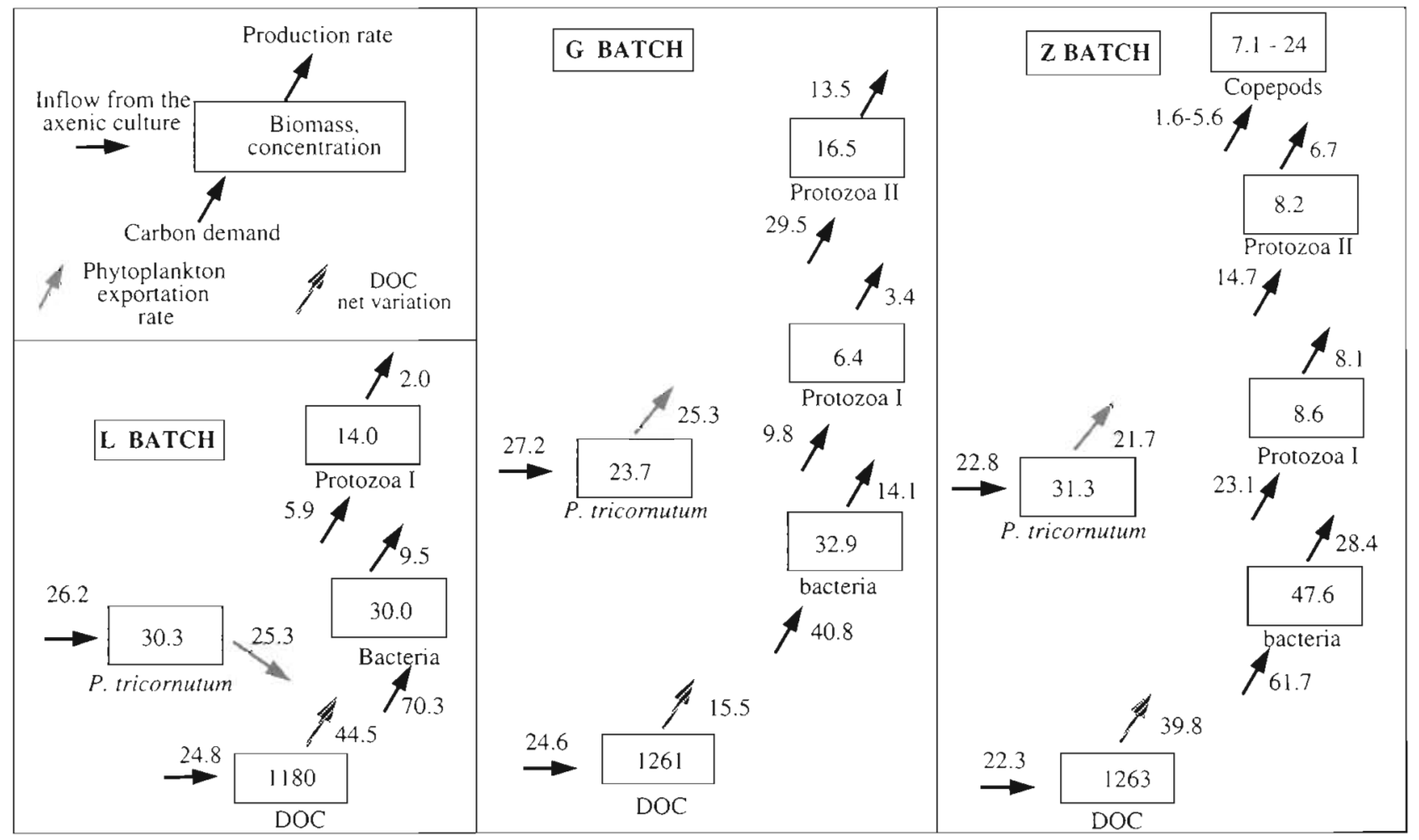

Fig. 6. Provisional carbon budgets for the microbial food web in the 3 batches from Day 5 to Day 18 . Numbers within boxes indicate average biomasses ( $\mu \mathrm{g} \mathrm{Cl}^{-1}$ ) or concentration of dissolved organic carbon (DOC, $\mu \mathrm{g} \mathrm{C}^{-1}$ ). Left horizontal arrows represent inflow from the axenic culture $\left(\mu \mathrm{g} \mathrm{C} \mathrm{l}^{-1} \mathrm{~d}^{-1}\right)$. The outward arrow for the DOC represents a net variation. Inward and outward arrows for bacteria, protozoa I, protozoa II and copepods represent carbon demand and production rates, respectively ( $\mu \mathrm{g} \mathrm{C}^{-1}$ $\left.\mathrm{d}^{-1}\right)$. Protozoa l: bacterivorous flagellates $(<8 \mu \mathrm{m})$; Protozoa II: protozoa able to ingest Phaeodactylum tricornutum ( $\left.>8 \mu \mathrm{m}\right)$. The 2 values in the box of copepods represent the range of biomasses observed in the batch

variation of Phaeodactylum tricornutum respectively. The growth yields were, $13.5,34.5$ and $46 \%$ in $\mathrm{L}, \mathrm{G}$ and $C$ respectively.

The cumulative exportation fluxes of bacteria approached those of their production (Table 2). However, the bacterial biomass produced and exported was greater in $Z$ than in $G$ and $L(Z>G>L)$. The ingestion rates of bacterivorous flagellates were calculated from bacterial exportation flux and flagellate abundance on a daily basis from Day 5 to 29. The average values of ingestion rates of bacterivorous flagellates (Group I) were $7 \pm 4$ and $30 \pm 27$ bacteria cell ${ }^{-1} \mathrm{~h}^{-1}$, in $\mathrm{L}$ and $Z$ respectively. Unlike $L$ and $Z$, in $G$ some extremely high ingestion rate values (up to 963 bacteria cell $^{-1} \mathrm{~h}^{-1}$ ) for nanoflagellates were obtained when ciliates were present, suggesting that ciliates were also ingesting bacteria. In this case, ingestion rates of bacteria by ciliates, calculated from bacterial exportation fluxes, would be $1.5 \pm 1.3 \times 10^{3}$ bacteria ciliate ${ }^{-1} \mathrm{~h}^{-1}$. The ingestion rates of phytoplankton by ciliates in $G$, calculated from phytoplankton losses, ranged from 1.7 to 19 cells ciliate ${ }^{-1} \mathrm{~h}^{-1}\left(9 \pm 10\right.$ cells ciliate $\left.\mathrm{e}^{-1} \mathrm{~h}^{-1}\right)$. The average growth yields for bacterivorous flagellates, calculated from exportation fluxes of their potential prey (bacteria), was $35 \%$. The growth yield of ciliates, calculated from exportation fluxes of bacterivorous flagellates and phytoplankton daily variation, was $45.6 \%$. The calculated generation time of the ciliates was $20 \mathrm{~h}$.

Carbon budgets (Table 2, Fig. 6) were set up for each enclosure to summarize major food web characteristics of the enclosed system, with respect to pool sizes and flow rates. For these provisional carbon budgets, we considered the time period from Day 5 to Day 18 for which DOC data were available. The carbon demand of bacteria was calculated from bacterial production using the respective growth yields reported above. The carbon demand of 'Protozoa I' (bacterivorous flagellates, Fig. 6) was assumed to be equal to bacterial exportation fluxes. Their production was calculated using an average growth yield of $35 \%$. For 'Protozoa II' (protozoa able to ingest Phaeodactylum tricornutum, Fig. 6), production rates and carbon demand were calculated assuming a generation time of $20 \mathrm{~h}$, and a growth yield of $45.6 \%$ (see above). The copepod carbon demand was calculated from respiration rates measured on Days 18 and 26 (Eq. 1). 


\section{DISCUSSION}

Conceptual models usually suggest that the process responsible for phytoplankton losses can be different depending on the type of top predator (Fig. 2). Suprisingly, the collapse of phytoplankton was synchronous in the 3 batches, suggesting a common origin for such a collapse, such as predation, nutrient exhaustion, viral lysis or sedimentation.

First, nutrient measurements show that nutrient exhaustion was probably not the reason for the phytoplankton collapse. Nitrates and nitrites stabilized at around $1.5 \mu \mathrm{M}$ and $0.26 \mu \mathrm{M}$, respectively, in the 3 batches and phosphorus and ammonium increased by remineralization processes, up to $1,6,2.5$ and $3.8 \mu \mathrm{M}$ $N$ and $0.28,0.21$ and $0.25 \mu \mathrm{MP}$ in batches $\mathrm{G}, \mathrm{L}$ and Z, respectively (M. Pujo-Pay \& P. Raimbault pers. comm.).

Second, measurements of biochemical descriptors (such as lipids, ATP, and chorophyll; M. Goutx \& J. C. Romano pers. comm.) in the batches indicate some significant biochemical changes of phytoplankton cells just before the population collapsed. Highly dynamic changes of cell biochemistry are associated with senescent phase of diatom blooms (Morris et al. 1983). In our experiment, detritus-like particles, algal 'ghosts' and free chloroplasts were present after Day 13, especially in the $\mathrm{L}$ and $\mathrm{Z}$ batches. Concomitantly, increase of triglycerides inside the particulate material occurred from Days 10 to 14 in L and could likely be related to the accumulation of ageing Phaeodactylum tricornutum cells undergoing changes from protein to lipid anabolism (Goutx pers. comm.). In contrast, in G, triglycerides did not increase as much as in $\mathrm{L}$ and membrane tracers of $P$. tricornutum (phosphatidylcholine) did not appear in the dissolved phase. Apparently, in $\mathrm{G}$, senescent phytoplankton was disappearing rapidly, suggesting active grazing by ciliates.

Little is known concerning viral attacks on phytoplankton (Suttle 1994). In the L vessel, regardless of the cause of the collapse of the phytoplankton (autolysis, viral lysis or bacterial lysis), lysed by-products could be further utilized by bacteria. In $G$, the results on lipid composition and microscopical observations suggest that the main reason for phytoplankton loss was grazing by ciliates.

At least some sedimentation of accumulated phytoplankton is not excluded, however biochemical descriptors such as the lipid/chlorophyll, chlorophyll/cell and chl/ATP ratios (Goutx \& Romano pers. comm.) demonstrated strong variations in the 3 batches, indicating that the senescent diatoms were mainly remaining in suspension. At the end of the experiment, the bottom of the vessels was checked. We observed some particulate detritus and copepod faecal pellets (in Z).
Neither entire Phaeodactylum tricornutum cells nor free chloroplasts were observed.

During the aggregation phase, classically described as part of the cycle of decay of phytoplankton blooms (Biddanda \& Pomeroy 1988, Van Wambeke 1994), flagellates colonize senescent phytoplankton cells, taking advantage of the enriched microenvironments (Newell et al. 1981, Bjørnsen et al. 1988). The most pronounced protozoa-phytodetritus association occurred in the $\mathrm{L}$ container (Days 13 to 21 ), suggesting that the mode of phytoplankton loss affected the duration of the aggregation phase. Moreover, the cumulative biomass/POC ratio was highest in the $Z$ and lowest in the $L$ batch, implying a lower level of detritus present in $Z(Z<G<$ $L)$. This suggests that the complexity of the food web can influence the turnover rates of detritus in the water column.

When grazers of phytoplankton were present (e.g. ciliates, copepods), the bacteria were likely further fueled by grazing by-products (excretion, defecation and sloppy feeding). Therefore, we can assume that the presence of grazers and detritus feeders stimulated bacterial growth and thus the rate of decomposition (Johannes 1965, Taylor et al. 1985, Fenchel \& Harrison 1986, Bjørnsen et al. 1988, Roman et al. 1988) as well as the subsequent increase of the bacterial growth such as observed in $Z$ ( $Z>G>L$ ). Copepods stimulated all the parameters of bacterial activity. Measurements of leucine assimilation rates in the 3 batches showed the same pattern as bacterial production rates $\left(Z>G>L_{\text {; }}\right.$ Christaki 1995). However, the balance between bacterial production and exportation rates observed throughout the experiment in the 3 batches suggests a rapid functional response of the microbial food webs to the degree of perturbations (e.g. number of predator categories) of the ecosystem structure (Bjørnsen et al. 1988, Roman et al. 1988, Sherr et al. 1988, KuuppoLeinikki et al. 1994). In a recent study, using enclosures manipulated with nutrients and a top predator, Kuuppo-Leinikki et al. (1994) showed that the amplitudes of oscillations between coupled communities were increased, while the frequencies of oscillations lasted unchanged.

In order to calculate ingestion rates and growth yields, we assumed that protozoa were exclusively responsible for the consumption of bacterial biomass. The calculated ingestion rates for protozoa in the $\mathrm{L}$ and $Z$ containers $\left(7 \pm 4\right.$ and $30 \pm 19$ bacteria cell ${ }^{-1} \mathrm{~h}^{-1}$ respectively) fall within the values reported in the literature (Bjørnsen et al. 1988, Vaqué et al. 1994). High values (up to several hundreds of bacteria cell-1 $\mathrm{h}^{-1}$ ) were obtained in $\mathrm{G}$ when ciliates were present. Some ciliates can feed directly on bacteria (Rivier et al. 1985): thus, a possible utilisation of bacteria by ciliates is not excluded considering the bacterial abundance reached 
in $\mathrm{G}$. In $\mathrm{G}$, the ciliates constituted the top predator and were able to feed on both Phaeodactylum tricornutum and nanoflagellates. The opportunistic nature of the ciliates seems common and related to adaptation in food resources and high ingestion rates (Stoecker \& Evans 1985, Wikner \& Hagström 1988, Weisse \& Scheffel-Möser 1991, Kuuppo-Leinikki et al. 1994). The calculated generation time $(20 \mathrm{~h})$ and growth yield $(45.6 \%)$ of ciliates is in agreement with previous observations on protozoa in mesocosms (Riemann et al. 1990). The carbon demand of 'Protozoa II' calculated from these coefficients could be satisfied by simultaneous utilisation of 'Protozoa I' production and phytoplankton exportation (Fig. 6).

Our carbon budgets are intended to summarize major food web characteristics of the enclosed system, with respect to pool sizes and flow rates. In such an attempt, some or many assumptions are made (Newell \& Linley 1984, Riemann et al. 1990). For example, the calculations of ingestion rates and bacterial growth yield do not take into account the possibility of lysis by viruses. Recent studies (Steward et al. 1992) suggest that viruses can be a significant source of bacterial mortality especially in highly productive coastal waters. Overall, results reported in the literature show that, on average, about $20 \%$ of marine heterotrophic bacteria are infected and 10 to $20 \%$ of the bacterial community is lysed daily by viruses (Suttle 1994 and references therein). Fuhrman (1992) suggested that significant bacterial losses to viruses has the somewhat unexpected results of (1) leading to increased gross bacterial production, and (2) decreasing availability of bacterial carbon to higher trophic levels. Nevertheless, the growth yields obtained for bacteria (13 to $46 \%$ ) and nanoflagellates (35\%) and the grazing rates of nanoflagellates feeding on bacteria are also in the ranges reported in the literature (Vaqué et al. 1994). All in all, bacterial viruses were certainly present in our microcosms, however the reasonable yields obtained, despite the assumptions made here, suggest that the main reason for bacterial mortality in the batches was predation by protozoa.

In the $Z$ batch, the distinct time periods defined by multivariate analysis were not related to presence or absence of copepods, suggesting that the succession within the microbial food web was not regulated by mesozooplankton (Bjørnsen et al. 1988, Riemann et al. 1990). Bacteria, flagellates, and ciliates dominated heterotrophic carbon flow processes in the batches. Similar results have been reported for both coastal waters and mesocosm studies (Joiris et al. 1982, Riemann et al. 1990).

Copepods have a well-documented omnivorous feeding behaviour (Paffenhöfer \& Knowles 1980, Landry 1981). Moreover, Acartia clausi and Cen- tropages typicus have been found to select ciliates over diatoms and dinoflagellates (Wiadnyana \& Rassoulzadegan 1989). Kopylov et al. (1981) reported that $A$. clausi did not graze on free nanoflagellates but actively utilized flagellates attached on detritus. Sheldon et al. (1986) observed that the copepod Euterpina acutifrons did not prey on free diatoms, but grazed on ciliates. This is in agreement with our observation in the $Z$ vessel where when copepods were present, protozoa $>10 \mu \mathrm{m}$ were rare, and ciliates were virtually absent. Conversely, heterotrophic nanoflagellates $(<10 \mu \mathrm{m})$ increased in the presence of mesozooplankton; this was more likely due to the increase of bacterial food resources and the reduction of the predation pressure by large protozoa (McCormick \& Cairn 1991). Copepods could affect the microbial food web in 2 ways: (1) by preying on protozoa and (2) by supplying dissolved organic carbon and nitrogen, for bacteria (Eppley et al. 1981, Roman et al. 1988). Mesozooplankton therefore probably have only an indirect influence over the bacteria-phytoplankton coupling (Vaqué et al. 1989).

Copepod production rates were not examined in our study but a carbon demand for copepods, calculated from respiration rates, is used to give an indication of the carbon needed per copepod per day. The carbon demand calculated from respiration of animals in the $Z$ container could efficiently be met by 'Protozoa II' production. An alternative approach to obtain an estimate of the copepod carbon demand is to consider that they need food, according to a certain percentage of their biomass expressed in $\mu \mathrm{g} \mathrm{C} \mathrm{d}^{-1}$ However, this percentage is also highly variable (e.g. Gaudy 1974, Tester \& Turner 1988); thus we used for comparison an average $40 \%$ value, as proposed in Newell \& Linley (1984) for adult copepods. When calculated on the basis of $40 \%$ of the biomass (Newell \& Linley 1984), this carbon demand was almost 2 -fold higher (4 and $9.6 \mu \mathrm{g} \mathrm{C} \mathrm{^{-1 }}$ $\mathrm{d}^{-1}$ for minimum and maximum biomass, respectively) than the one deduced from respiration rate. The respiration rate of copepods was measured on specimens incubated in unfiltered $Z$ batch water. However, we cannot be sure that the quantity of food available in the experimental flasks was sufficient. Kiørboe et al. (1985) showed that the respiration rates of fed copepods can be up to 4 -fold higher than starved ones. Nevertheless, the carbon available to copepods (Phaeodactylum tricornutum + Protozoa II) in Z was sufficient to meet a demand up to 4-fold higher from the one reported in Fig. 6.

The microzooplankton ( $\mathrm{G}$ container) had a greater grazing impact on phytoplankton than copepods ( $Z$ vessel). In pelagic ecosystems, during certain seasons, the grazing impact of ciliates can be greater than that of copepods (Turner \& Granéli 1992). However, in the 
microcosms of this study we could observe the grazing impact of ciliates upon phytoplankton only in the absence of copepods. As suggested by Wiadnyana \& Rassoulzadegan (1989) and Turner \& Granéli (1992) copepods appear to be selective predators of the real predators (protozoa) of phytoplankton. Moreover, the decrease of heterotrophs lable to ingest the Phaeodactylum tricornutum) by copepods in $\mathrm{Z}$ made available a considerable fraction of the phytoplankton to be lysed by bacteria.

Overall, it appears that the processes of phytoplankton loss depend on the net result of complex food web interactions. The presence of a complex food web leads to the acceleration of the carbon transfer within it. This acceleration is not only represented by a higher number of bacteria, it is particularly related to their capacity of adaptation to new resources. This adaptation is reflected in their higher specific rates. The general trend of the parameters describing the microbial activity was $Z>G>L$. The influence of the complexity of the system on the turnover rate of organic matter is also evidenced by the ratio cumulative biomass/POC, which indicated a lower level of detritus when predators of phytoplankton were present. The transfer of material from one trophic level to the next leads to a considerable loss of energy. However, the existence of many trophic levels counterbalances this loss by a faster transfer of this material through trophic levels which consequently leads to a higher benefit of this matter by the whole food web.

Acknowledgements. This work was supported by a Ph.D. scholarship to U.C. (CEC B/MAST/913008). We are grateful to Drs G. Copin-Montégut (Laboratoire de Physique et Chimie Marines, Villefranche), M. Goutx (Laboratoire de Microbiologie Marine), M. Pujo-Pay (Centre Océanologique de Marseille, COM), P. Raimbault (COM) and J C. Romano (COM) for provision of unpublished data and Dr R. Gaudy (COM) for his help in copepod experimentation. We are grateful to Dr M. Bianchi. Prof, D. Bonin and Dr D. Vaque for comments of the manuscript. We thank 3 anonymous reviewers for their constructive criticisms of an earlier version of the manuscript.

\section{LITERATURE CITED}

Biddanda BA, Pomeroy LR (1988) Microbial aggregation and degradation of phytoplankton-derived detritus in seawater. I. Microbial succession. Mar Ecol Prog Ser 42:79-88

Bjørnsen PK, Riemann B, Horsted SJ, Nielsen TG, Pock-Sten $J$ (1988) Trophic interactions between heterotrophic nanoflagellates and bacterioplankton in manipulated seawater enclosures. Limnol Oceanogr 33:409-420

Børsheim KY, Bratbak G (1987) Cell volume to cell carbon conversion factors for a bacterivorous Monas sp. ennched from sea water. Mar Ecol Prog Ser 36:171-175

Cho BC. Azam F (1988) Major role of bacteria in biochemical fluxes in the ocean's interior. Nature 332:441-443

Christaki U (1995) Régulations trophiques et interactions microbiennes en milieu pélagique, rélations avec les métazoaoires. Thèse de Doctorat Océanologie, Université d'Aix Marseille II

Eppley RAW, Horrigan SAG, Fuhrman JA, Brooks ER, Price CC, Sellner K (1981) Origins of dissolved organic matter in Southern California coastal waters: experiments on the role of zooplankton. Mar Ecol Prog Ser 6:149-159

Fenchel T, Harrison P (1976) The significance of bacterial grazing and mineral cycling for the decomposition of particulate detritus. In: Anderson JM, Macfadyen A (eds) The role of terrestrial and aquatic organisms in decomposition processes. Blackwell Scientific Publications, Oxford, P 285-299

Field JG, Clarke KR, Warwick RM (1982) A practical strategy for analyzing multispecies distribution patterns. Mar Ecol Prog Ser 8:37-52

Fuhrman JA (1992) Bacterioplankton roles in cycling of organic matter: the microbial food web. In: Falkowski PG Woodhead AD (eds) Primary productivity and biochemical cycles in the sea. Plenum Press, New York, p 361-383

Fuhrman JA, Azam F (1982) Thymidine incorporation as a measure of heterotrophic production in marine surface waters. Evaluation and field results. Mar Biol 66:109-120

Gaudy R (1972) Contribution à l'étude du cycle biologique des copépodes pélagiques du Golfe de Marseille 1. L'environnement physique et biotique et la composition de la population des copépodes. Tethys 3:921-942

Gorsky G, Dallot S, Sardou J, Fenaux R, Carré C, Palazzoli I (1988) Carbon and nitrogen composition of some North Mediterranean zooplankton and micronekton species. $\mathrm{J}$ exp mar Biol Ecol 124:133-144

Gaudy R (1974) Feeding four species of pelagic copepods under experimental conditions. Mar Biol 25:125-141

Johannes RE (1965) Influence of marine protozoa on nutrient regeneration. Limnol Oceanogr 10:434-442

Joiris C, Billen G, Lancelot C, Daro MH, Mommaerts JP, Bertels A, Bossicart M, Nijs J, Hecq JH (1982) A budget of carbon cycling in the Belgian coastal zone: relative roles of zooplankton, bacterioplankton and benthos in the utilisation of primary production. Neth J Sea Res 16:260-275

Keller AA, Riebesell U (1989) Phytoplankton carbon dynamics during a winter-spring diatom bloom in an enclosed marine ecosystem: primary production, biomass and loss rates. Mar Bio] 103:131-142

Kirchman D, Ducklow H, Mitchell R (1982) Estimates of bacterial growth from changes in uptake rates and biomass Appl environ Microbiol 44:1296-1307

Kiørboe T, Møhlenberg F, Hamburger K (1985) Bioenergetics of the planktonic copepod Acartia tonsa: relation between feeding, egg production and respiration, and composition of specific dynamic action. Mar Ecol Prog Ser 26:85-97

Kopylov AI, Pasternak AF, Moiseyev YV (1981) Consumption of zooflagellates by planktonic organisms. Oceanology $2 i$ 375-379 (in Russian)

Kuuppo-Leinikki P, Autio R, Hällfors S, Kuosa H, Kuparinen J, Pajuniemi R (1994) Trophic interactions and carbon flow between picoplankton and protozoa in pelagic enclosures manipulated with nutrients and a top predator. Mar Ecol Prog Ser 107:89-102

Landry MR (1981) Switching between herbivory and carnivory by the planktonic marine copepod Calanus pacificus. Mar Biol 65:77-82

Lee S, Fuhrman JA (1987) Relationships between biovolume and biomass of naturally derived marine bacterioplankton. Appl environ Microbiol 53:1298-1303

Legendre L, Le Fèvre J (1989) Hydrodynamical singularities as control of recycled versus export production in the 
oceans, In: Berger WH, Smetacek VS, Wefer G (eds) Dahlem Workshop on Productivity of the Ocean, Present and Past. John Wiley \& Sons, Berlin, p 49-63

Lucas MI (1986) Decomposition in pelagic marine ecosystems. J Limnol Soc S Afr 12:99-122

McCormick PV, Gairns J Jr (1991) Effects of micrometazoa on a protistan assemblage of a littoral food web. Freshwat Biol 26:111-119

Morris RJ, McCartney MJ, Robinson GA (1983) Studies of a spring phytoplankton bloom in an enclosed experimental ecosystem; I: Biochemical changes in relation to the nutrient chemistry of water J exp mar Biol Ecol 70:249-262

Newell RC, Linley EAS (1984) Significance of microheterotrophs in the decomposition of the phytoplankton: estimates of carbon and nitrogen flow based on the biomass of plankton communities. Mar Ecol Prog Ser 16:105-119

Newell RC, Lucas MI, Linley EAS (1981) Rate of degradation and efficiency of conversion of phytoplankton debris by marine microorganisms. Mar Ecol Prog Ser 6:123-136

Omori M, Ikeda I (1984) Methods in marine zooplankton ecology. John Wiley and Sons, New York

Paffenhöfer GA, Knowles SC (1980) Omnivorousness in marine planktonic copepods. J Plankton Res 2:335-365

Painting SJ, Lucas MI, Muir DG (1989) Fluctuations in heterotrophic bacterial community structure, activity and production in response to development and decay of phytoplankton in a microcosm. Mar Ecol Prog Ser 53: $129-141$

Pomeroy LR. Wiebe WJ (1988) Energetics of microbial food webs. Hydrobiologia 159:7-18

Putt M, Stoecker DK (1989) An experimentally determined carbon:volume ratio for marine 'oligotrichous' ciliates from estuarine and coastal waters. Limnol Oceanogr 34 : $1097-1103$

Riemann B, Bjørnsen PK, Newell SY, Fallon R (1987) Calculation of cell production of coastal marine bacteria based on measured incorporation of $\left[{ }^{3} \mathrm{H}\right]$ thymidine. Limnol Oceanogr 32:471-476

Riemann B, Sørensen HM, Bjørnsen PK, Horsted SJ, Jensen LM, Nielsen TG, Søndergaard M (1990) Carbon budgets of the microbial food web in estuarine enclosures. Mar Ecol Prog Ser 65:159-170

Rivier A, Brownlee DC, Sheldon RW, Rassoulzadegan F (1985) Growth of microzooplankton: a comparative study of bactivorous zooflagellates and ciliates. Mar microb Food Webs 1:51-60

Roman MR, Ducklow HW, Fuhrman JA, Garside C, Glibert PM, Malone TC, McManus GB (1988) Production, consumption and nutrient cycling in a laboratory mesocosm. Mar Ecol Prog Ser 42:39-52

Sheldon EW, Nival P. Rassoulzadegan F (1986) An experimental investigation of a flagellate-ciliate-copepod food chain with some observations relevant to the linear biomass hypothesis. Limnol Oceanogr 31:184-188

Sherr BF, Sherr EB, Hopkinson CS (1988) Trophic interactions within pelagic microbial communities: indications of feedback regulation of carbon flow. Hydrobılogia 159:12-26

Steward GF, Wikner JDC, Cochlan Smith WP, Azam F (1992) Estimation of virus production in the sea: II. Field results. Mar microb Food Webs 6:57-78

Stoecker DK, Evans GT (1985) Effects of protozoan herbivory and carnivory in a microplankton food web. Mar Ecol Prog Ser 25:159-167

Strickland JDH, Parsons TR (1972) A practical handbook of seawater analysis, 2nd edn. Bull Fish Res Bd Can 167

Sumigura Y, Suzuki Y (1988) A high temperature catalytic oxidation method of non-volatile dissolved organic carbon in seawater by direct injection of a liquid sample. Mar Chem 24:105-131

Suttle CA (1994) The significance of viruses to mortality in aquatic microbial communities. Microb Ecol 28:237-243

Taylor GT, Iturriaga R, Sullivan CW (1985) Interactions of bacterivorous grazers and heterotrophic bacteria with dissolved organic matter. Mar Ecol Prog Ser 35:99-109

Tester PA, Turner JT (1988) Comparative carbon-specific ingestion rates of phytoplankton by Acartia tonsa, Centropages veliicatus and Eucalanus pileatus grazing on natural phytoplankton assemblages in the plume of the Mississippi River (northern Gulf of Mexico continental shelf). Hydrobiologia 167/168:211-217

Turner JT, Granéli E (1992) Zooplankton feeding ecology: grazing during enclosure studies of phytoplankton blooms from the west coast of Sweden. J exp mar Biol Ecol 157: $19-31$

Van Wambeke F (1994) Influence of phytoplankton lysis or grazing on bacterial metabolism and trophic relationships. Microb Ecol 27:143-158

Vaqué D, Gasol JM, Marrasé C (1994) Grazing rates on bacteria: the significance of methodology and ecological factors. Mar Ecol Prog Ser 109:263-274

Vaqué D, Marrasé C, Iñiquez V, Alcaraz M (1989) Zooplankton influence on the phytoplankton-bacterioplankton coupling. J Plankton Res 11:625-632

Weisse T, Scheffel-Möser U (1991) Uncoupling the microbial loop: growth and grazing loss rates of bacteria and heterotrophic nanoflagellates in the North Atlantic. Mar Ecol Prog Ser 71:195-205

Wiadnyana NN, Rassoulzadegan F (1989) Selective feeding of Acartia clausi and Centropages typicus on microzooplankton. Mar Ecol Prog Ser 53:37-45

Wikner J, Hagström $\AA$ (1988) Evidence for a tightly coupled nanoplanktonic predator-prey link regulating the bacterivores in the marine environment. Mar Ecol Prog Ser 50: $137-145$ 